\title{
Synchronous or Asynchronous: Students' Perceptions on Online Learning During the Pandemic
}

\author{
Yulitriana $^{1 *}$ \\ ${ }^{1}$ The Study Program of English Education, Faculty of Teacher Training and Education \\ University of Palangka Raya
}

\begin{abstract}
The terms synchronous and asynchronous learnings are becoming trendy nowadays as the full online learning is conducted in all levels of education in order to prevent the Covid-19 pandemic outbreak. Accordingly, it is prominent to investigate students' perceptions towards synchronous and asynchronous learning based on their experiences in online learning during this pandemic. Survey design was used in this research and the sample were 42 students of English Education Study Program at a public university in Palangka Raya. The data were collected from the responses of questionnaire given to the students. The result indicates that the synchronous and asynchronous activities in online learning gives new experience for the students, and they prefer the combination of both in their online learning instead of having only synchronous or asynchronous meetings most of the time. Synchronous meetings equip the students when dealing with new or complicated concepts and keep their interest in learning while the asynchronous ones give the students their personal pace in learning as they can adjust their time and speed.
\end{abstract}

Keywords: synchronous, asynchronous, students' perceptions, online learning, pandemic

\section{INTRODUCTION}

This article was based on a research conducted in an online class at English Education Study Program of a public university in Palangka Raya during the Covid-19 pandemic outbreak in even semester in academic year 2020/2021. This pandemic consequently switched all the teaching learning activities into online, and definitely, having a full online learning was an unpredictable and shocking experience for both students and teachers. They tried to adapt to this situation; however, it was not that easy as in the beginning as the full online learning was conducted without sufficient preparation. Moreover, "the online course may not address the social and emotional aspects of learning in the same way the face-to-face tutoring and interactions would." (Bosch, 2016). Obviously, both students and teachers could not deny that offline learning and online learning are different in some ways, and some issues emerged on how to build the engagement in the online learning itself were very challenging.

The online learning during this pandemic has also emerged the terms synchronous and asynchronous into popularity and designing and conducting e-learning means "combining the right mix of synchronous and asynchronous activities" (Naidu, 2006); (Howard, L., Remenyi, Z., \& Pap, n.d.); (Piskurich, 2006). These two terms have even brought the blended learning into a new perspective as it has been adapted to the situation.

\footnotetext{
*Corresponding author: yulitriana@edu.upr.ac.id

To cite this article: Yulitriana (2021). Synchronous or Asynchronous: Students' Perceptions on Online Learning During the Pandemic. Ebony --- Journal of English Language Teaching, Linguistics, and Literature, 1 (1) 2021, pp. 54--59.
} 
Before the pandemic, blended learning was more recognized as the mixture of face to face (offline) meetings and online meeting. During this Covid-19 pandemic, blended learning is a learning system that "combines synchronous and asynchronous learning strategies appropriately in such a way to create an optimum learning experience to achieve the specific predetermined learning outcomes." (Chaeruman, U. A.; Wibawa, B.; Syahrial, 2020). It can be concluded that having the insights on how the synchronous and asynchronous activities should be elaborated are very crucial in online learning as they will contribute to success of the teaching learning activities. It is also supported by Sana et al that "Synchronous and asynchronous learning mode and a thoughtful integration of the both modes leading to a complete sufficient learning in the light of blended approach (Sana et al., 2018). When an online learning is organized in such a way that facilitates both the synchronous and asynchronous activities, it means that it has successfully provided a comprehensive and adequate learning for students.

As knowledge and skills in technology and online learning have been more developed, there is also a curiosity to investigate students' perceptions towards synchronous and asynchronous learning based on their experiences in online learning during this pandemic. Hopefully, this article can contribute to enrich the teachers' knowledge in online class, and how they can improve and develop the available sources for their online teaching and learning in terms of synchronous and asynchronous learning in order to meet the needs of their students. Therefore, the following research question guides the whole part of this study: "what are the students' perceptions towards the synchronous and asynchronous learning during the Covid-19 pandemic?"

\section{METHODS}

This research uses a survey design which "provides quantitative or numeric description of trends, attitudes, or opinions of a population by studying a sample of that population." (Creswell, 2009). Therefore, the objective of this research is to find and analyze the data related to students' perception on online learning during the Covid-19 pandemic regarding the synchronous and asynchronous learning. The sample used were 42 students of English Education Study Program at a public university in Palangka Raya. The students were in the fourth semester in academic year 2020/2021. The data were collected from the responses of questionnaire given to the students by using Google Form.

\section{RESULTS}

The questions asked in the questionnaire try to reveal the students' perceptions towards the synchronous and asynchronous learning. The first table presents the data related to students' preference whether synchronous learning or asynchronous learning that they consider more appropriate. 
Table 1. Students Perceptions Towards Synchronous and Asynchronous Learning

\begin{tabular}{|c|c|c|c|}
\hline \multirow{2}{*}{ Category } & \multirow{2}{*}{ Questions } & \multicolumn{2}{|c|}{ Responses } \\
\hline & & Syn? & Asyn? \\
\hline \multirow{7}{*}{$\begin{array}{c}\text { Synchronous } \\
\text { Learning } \\
\text { or } \\
\text { Asynchronous } \\
\text { Learning? }\end{array}$} & $\begin{array}{l}\text { 1) Which learning is more effective when applying } \\
\text { new knowledge? }\end{array}$ & $69 \%$ & $31 \%$ \\
\hline & $\begin{array}{l}\text { 2) Which type of learning is more effective to } \\
\text { facilitate your needs to have comprehension on the } \\
\text { materials? }\end{array}$ & $78.6 \%$ & $21.4 \%$ \\
\hline & $\begin{array}{l}\text { 3) Which type of learning is more effective to get } \\
\text { feedback from teachers? }\end{array}$ & $64.3 \%$ & $35.7 \%$ \\
\hline & $\begin{array}{l}\text { 4) Which type of learning makes you more interested } \\
\text { in learning? }\end{array}$ & $71.4 \%$ & $28.6 \%$ \\
\hline & $\begin{array}{l}\text { 5) Which type of learning keeps your interest in } \\
\text { learning? }\end{array}$ & $66.7 \%$ & $33.3 \%$ \\
\hline & 6) Which type of learning fits your learning style? & $64.3 \%$ & $35.7 \%$ \\
\hline & 7) Which type of learning fits your time for learning? & $40.5 \%$ & $49.5 \%$ \\
\hline
\end{tabular}

Note: Syn=Synchronous Learning; Asyn=Asynchronous Learning

First of all, the students' responses in Table 1 number 1 show that synchronous learning is more effective when they have to apply new knowledge in learning (69\%). It is related to the other responses in Table 2 number 1 (21.4\% strongly agree and $71.4 \%$ agree) which state that the students need to have direct explanation from their teachers (synchronous learning) when they learn new concepts.

Table 2. Students Perceptions Towards Synchronous Learning

\begin{tabular}{|c|c|c|c|c|}
\hline \multirow{2}{*}{ Category } & \multirow{2}{*}{ Questions } & \multicolumn{3}{|c|}{ Responses } \\
\hline & & SA & $\mathbf{A}$ & D \\
\hline \multirow{3}{*}{$\begin{array}{c}\text { Synchronous } \\
\text { Learning }\end{array}$} & $\begin{array}{l}\text { 1) It is necessary to get direct explanation from } \\
\text { teachers through synchronous meetings. }\end{array}$ & $21.4 \%$ & $71.4 \%$ & $7.1 \%$ \\
\hline & $\begin{array}{l}\text { 2) Synchronous meetings are necessary for small } \\
\text { group discussions. }\end{array}$ & $26.2 \%$ & $71.4 \%$ & $19 \%$ \\
\hline & $\begin{array}{l}\text { 3) Teachers should be available for students in } \\
\text { synchronous small group discussions. }\end{array}$ & $19 \%$ & $45.2 \%$ & $35.7 \%$ \\
\hline
\end{tabular}

Note: SA=Strongly Agree; $\mathrm{A}=$ Agree; $\mathrm{D}=$ Disagree

It is also supported by the students' needs for small group discussion (Table 2, question number 2) as $54.8 \%$ (agree) and $26.2 \%$ (strongly agree) of the students think that they need synchronous meetings, such as by using Zoom breakout rooms, for small group discussions. Moreover, in Table 2 number 3, according to $19 \%$ (strongly agree) and $45.2 \%$ (agree) of the students, by having synchronous video conference, their teachers can give them 
assistance when needed. Therefore, it is important for then that their teachers are available in synchronous group discussions when they ask for help.

Secondly, in Table 1 number 2, the students (78.6\%) think that synchronous learning is very helpful to develop their comprehension on the materials taught. In addition to that, Table 1 number 4 shows that synchronous learning makes the students more interested in learning $(71.4 \%)$, and not only making them more interested, synchronous learning is also more effective to keep their interest in the learning itself (Table 1 number 5). They also prefer to have direct feedback in synchronous learning (64.3\%) instead of feedback in asynchronous learning (Table 1 number 3$)$. They ((64.3\%) also consider that synchronous learning fits their learning style (Table 1 number 6). However, when it is dealing with the students' time for learning, they (59.5\%) consider asynchronous suits their time (Table 1 number 7).

In the last part of the questionnaire, the questions move to be more specific to synchronous and asynchronous as the blended learning.

Table 3. Blended Learning

\begin{tabular}{llccc}
\hline \multirow{2}{*}{ Category } & \multicolumn{1}{c}{ Statements } & \multicolumn{2}{c}{ Responses } \\
\cline { 2 - 5 } & $\begin{array}{l}\text { 1) } \begin{array}{l}\text { I like learning that combines synchronous and } \\
\text { asynchronous meetings. }\end{array} \\
\text { A }\end{array}$ & $47.6 \%$ & $40.5 \%$ & $11.9 \%$ \\
\cline { 2 - 5 } Blended & $\begin{array}{l}\text { 2) Other teachers should use learning media that } \\
\text { combine synchronous and asynchronous meetings. }\end{array}$ & $45.2 \%$ & $45.2 \%$ & $9.5 \%$ \\
\cline { 2 - 5 } Learning & \begin{tabular}{l} 
3) $\begin{array}{l}\text { Learning that combines synchronous and } \\
\text { asynchronous meetings gives me a new experience. }\end{array}$ \\
\cline { 2 - 5 }
\end{tabular} & $52.4 \%$ & $47.6 \%$ & $0 \%$ \\
\cline { 2 - 5 } & $\begin{array}{l}\text { 4) I like a course that combines synchronous and } \\
\text { asynchronous meetings instead of a course that only } \\
\text { has synchronous meetings. }\end{array}$ & $50 \%$ & $33.7 \%$ & $14.3 \%$ \\
\hline
\end{tabular}

Note: $\mathrm{SA}=$ Strongly Agree; $\mathrm{A}=$ Agree; $\mathrm{D}=$ Disagree

According to Table 3 number 1, most of the students (47\% strongly agree and $40.5 \%$ agree) like the blended learning which combines the synchronous and asynchronous learning in the process; and in addition, they also hope that other teachers can blend the synchronous and asynchronous learning in their online learning (Table 3 number 2). All the students (100\%) agree that the synchronous and asynchronous learning give new experience in learning for them. Finally, when the students have to choose, they prefer a course which combine synchronous and asynchronous learning (50\% strongly agreed and $35.7 \%$ agreed) to a course which only has synchronous learning (14.3\%).

\section{DISCUSSION}

Based on the result presented, it is obvious that most of the students prefer the blend of synchronous and asynchronous learning for their online learning. It is supported by Chaeruman, Wibawa, Syahrial (2020) that "blended learning is a learning system that 
combines synchronous and asynchronous learning strategies appropriately in such a way to create an optimum learning experience to achieve the specific predetermined learning outcomes." They prefer these two kinds of learning to be combined in online learning based on some reasons. The reasons for each are discussed as the following.

The first to be discussed is the synchronous learning. According to the students, this learning facilitates their needs for direct feedback from the teachers and small group discussion. Moreover, in synchronous learning, it is easier for them to ask for their teachers' assistance when they experience difficulties in learning. The most importantly, it builds the connection or engagement between the students and teachers and among the students' peers as they can have face to face meeting virtually in a small group or as a class. By listening to voice and looking at the facial expressions, it builds the engagement in the learning itself. Accordingly, the synchronous learning keeps the students' interest in learning. It is in line with the definition of students engagement that "student engagement refers to the degree of attention, curiosity, interest, optimism, and passion that students show when they are learning or being taught, which extends to the level of motivation they have to learn and progress in their education." ("Student Engagement," 2021). As students agreed that synchronous learning keep their interest in learning, the synchronous learning has a very to significant role to develop the engagement in the online learning and this also contributes to the progress and success of their learning. It does make sense as having been isolated in their house for months, the students should enjoy talking to their friends in a virtual discussion or in a virtual classroom. By having direct communication through the synchronous learning, it enables them to speak and to be listened as human by others.

However, the students do not agree if the online learning has synchronous meeting only (85.7\%). Furthermore, asynchronous learning is also considered important by the students as they can have their personal pace in the learning. It is also supported by Chaeruman who stated that "online asynchronous learning needs to be well facilitated by providing good quality learning object materials" (Chaeruman, 2021). For instance, when the teachers can share the learning materials in form of pdf files or video in the LMS (Canvas or Google Classroom) a few days before the synchronous meetings, students can adjust their time and speed to study the materials before their synchronous meetings. Therefore, they feel more prepared when they have their synchronous meetings. The LMS also organizes where and how the assignments given and submitted, thus it makes it easier for them to access the materials and assignment.

Indeed, there are parts of the learning which are more suitable to be learnt in synchronous learning as has been explained above, but there are parts which are more appropriate for asynchronous learning. Besides, the combination of synchronous and asynchronous activities in online learning gives new experience for the students. They realize they need their teachers especially when dealing with new or complicated concepts, however not in a context of being lectured most of the time. As students, they want small group discussions, and they need their teachers for feedback in discussion or when the concepts they are dealing with are too complicated to be solved in their small group. Afterward, in some classes, the students' works in the small group discussions are generally discussed again in the main group, in the class. Therefore, the finding in one group can enrich 
the knowledge and experience of the students in the other groups in learning. In this part, the role of the teachers as the facilitators are very crucial. Teachers should be able to digest the students' need and bring the essence of the materials in the classroom. Teachers should be able to highlight and emphasize the main points of all the activities students have during the meetings, to give corrections and feedback as necessary that cover both synchronous and asynchronous activities.

\section{CONCLUSION}

It is very enticing to find out that how the students enjoy their sense of independence in learning through the asynchronous learning, but at the same time they prefer their teachers function more as the facilitators in their learning instead of giving lectures most of the time. Being facilitators, it does not mean that the work will be a lot easier for the teachers as they should have comprehension and mastery on the materials better than the students as the students will address them with complicated concepts or projects they hardly deal with. Therefore, the teachers should be ready to guide and facilitate the students' needs with the knowledge and experiences regarding the topics being discussed both in the synchronous and asynchronous learning.

\section{REFERENCES}

Bosch, C. (2016). Promoting Self-Directed Learning through the Implementation of Cooperative Learning in a Higher Education Blended Learning Environment. SA: Doctoral dissertation at North-West University.

Chaeruman, U. A.; Wibawa, B.; Syahrial, Z. (2020). No TitleDevelopment of an Instructional System Design Model as a Guideline for Lecturers in Creating a Course Using Blended Learning Approach. International Journal of Interactive Mobile Technologies (IJIM) 14(14):1.

Chaeruman, U. A. (2021). Engaging Interaction in Online Asynchronous Learning A Sharing Experience in Applying COI Principles. June. https://doi.org/10.13140/RG.2.2.18129.45925

Creswell, J. W. (2009). Research Design: Qualitative, Quantitative, and Mixed Methods Approaches. Sage.

Howard, L., Remenyi, Z., \& Pap, G. (n.d.). Adaptive Blended Learning. 1.

Naidu, S. (2006). e-Learning: A Guidebook of Principles, Procedures and Practice. Commonwealth Educational Media Center.

Piskurich, G. (2006). Rapid Instructional Design. Pfeiffer, John Wiley and Sons, Inc H.

Sana, S., Adhikary, C., \& Chattopadhyay, K. N. (2018). Synchronous Vis-a-Vis Asynchronous Learning : A Blended Approach. 64431, 30-39.

Student Engagement. (2021). In The Glosary of Education Reform. https://www.edglossary.org/student-engagement/ 